\title{
Alfaxalone activates Human Pregnane-X Receptors with greater efficacy than Allopregnanolone: an in-vitro study with implications for neuroprotection during anesthesia.
}

Juliet.M. Serrao $\mathrm{PhD}^{\text {II }}$, and Colin.S. Goodchild $\mathrm{PhD}$ *,I,

Drawbridge Pharmaceuticals Pty Ltd, Malvern, Victoria, Australia

*Corresponding Author: Email: colin@drawbridgepharmaceuticals.com.au (CSG)

II These authors contributed equally to this work: planning of the experiments; collating and analyzing data; writing of the manuscript.

Data presented herein were submitted to the meeting of the International Research Society planned for May 2020 but then cancelled because of COVID19 pandemic

\section{Funding}

This project was funded by Drawbridge Pharmaceuticals Pty Ltd.

\section{Abbreviated Title: alfaxalone activates pregnane-X receptors}

\section{Conflicts of Interests}

Juliet M Serrao and Colin S Goodchild both have equity interests in Drawbridge Pharmaceuticals. Both are cited on Phaxan ${ }^{\mathrm{TM}}$ patents as inventors and they are both Directors and owners of Drawbridge Pharmaceuticals to which the Phaxan ${ }^{\mathrm{TM}}$ patents have been assigned.

\section{Abstract}

\section{Background}

Alfaxalone is a fast acting intravenous anesthetic with high therapeutic index. It is an analogue of the naturally-occurring neurosteroid, allopregnanolone which has been 
implicated in causing neuroprotection, neurogenesis and preservation of cognition, through activation of pregnane $\mathrm{X}$ receptors in the central nervous system. This study investigated whether alfaxalone can activate human pregnane $\mathrm{X}$ receptors (h-PXR) as effectively as allopregnanolone.

\section{Methods}

Allopregnanolone and alfaxalone were dissolved in dimethyl sulfoxide to make allopregnanolone and alfaxalone treatment solutions (serial 3-fold dilution concentration range, 50,000 - $206 \mathrm{nM})$. Activation of h-PXR by these ligand solutions compared with vehicle control was measured by an in-vitro method using human embryonic kidney cells (HEK293) expressing h-PXR hybridised and linked to the firefly luciferase gene. Ligand binding with and activation of h-PXR in those cells caused downstream changes in luciferase activity and light emission. That activity was measured as relative light units using a platereading luminometer, thus quantifying the changes in h-PXR activity caused by the ligand applied to the HEK293 cells. Ligand log concentration response curves were constructed to compare efficacy and potency of allopregnanolone and alfaxalone.

\section{Results}

Allopregnanolone and alfaxalone both activated the h-PXR to cause dose-related light emission by the linked firefly luciferase. Control solutions $(0.1 \%$ dimethyl sulfoxide $)$ produced low level light emissions. Equimolar concentrations of alfaxalone were more efficacious in activation of h-PXR: 50,000 nM, p = 0.0019; 16,700 nM, p = 0.0472; 5,600 $\mathrm{nM}, \mathrm{p}=0.0031$ [Brown-Forsythe and Welch ANOVA] 


\section{Conclusions}

Alfaxalone activates human-pregnane $\mathrm{X}$ receptors with greater efficacy compared with the endogenous ligand allopregnanolone. These results suggest that alfaxalone sedation and anesthesia may be accompanied by beneficial effects normally caused by the physiological effects of allopregnanolone, namely neuroprotection, neurogenesis, and preservation of cognition. 


\section{Introduction}

Pregnane X Receptor (PXR; NR112) is a nuclear receptor that binds with, and is activated by, a variety of xenobiotic and endogenous compounds, including naturally occurring steroids, pregnenolone, progesterone and allopregnanolone ${ }^{1 ; 2}$. Allopregnanolone is a metabolite of progesterone synthesized in the central nervous system where it promotes neurogenesis and neuroplasticity ${ }^{3 ; 4}$. PXR activation by allopregnanolone has also been linked to neuroprotection ${ }^{5}$. Further, these properties are due to PXR activation by allopregnanolone stimulating the production of brain-derived neurotrophic factor (BDNF) ${ }^{5-8}$. The most important functions of BDNF include: regulation of neuro-, glio-, and synapto-genesis; neuroprotection; and control of short- and long- lasting synaptic interactions responsible for memory and cognition ${ }^{9}$.

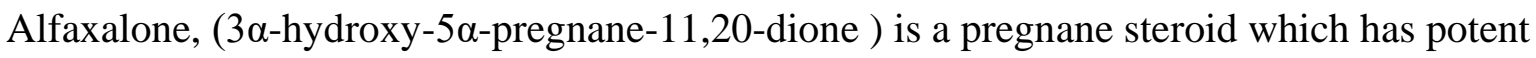
anesthetic and sedative properties by actions at gamma aminobutyric acid type $\mathrm{A}\left(\mathrm{GABA}_{\mathrm{A}}\right)$ receptors ${ }^{10}$. It is an allopregnanolone and progesterone analogue (Figure 1), but it is devoid of conventional progestogen or endocrine hormonal activity ${ }^{11}$. An aqueous formulation of alfaxalone (Phaxan $\left.{ }^{\mathrm{TM}}\right)$ has been developed for use as an intravenous sedative and anesthetic 12;13. This development occurs at a time when most commonly-used anesthetics are under investigation for neurotoxic effects ${ }^{14-16}$. Alfaxalone differs from those commonly used anesthetics in that it is a structural analogue of a naturally occurring neuroprotective hormone, allopregnanolone. It is unknown whether alfaxalone can activate human pregnane $\mathrm{X}$ receptors (h-PXR) although its structural similarity to allopregnanolone suggests that it may do so. If it is found that alfaxalone can activate mechanisms utilized by allopregnanolone to cause neuroprotection, e.g., PXR, there would be implications for the use 
bioRxiv preprint doi: https//doi org/10.1101/2020 09 05.284075. this version posted September 6, 2020. The copyright holder for this preprint (which was not certified by peer review) is the author/funder, who has granted bioRxiv a license to display the preprint in perpetuity. It is made available under aCC-BY-NC-ND 4.0 International license.

of alfaxalone in clinical anesthetic practice. This study set out to compare the activation of hPXR in-vitro by equimolar concentrations of allopregnanolone and alfaxalone.

Figure 1: Allopregnanolone and alfaxalone: molecular structures compared

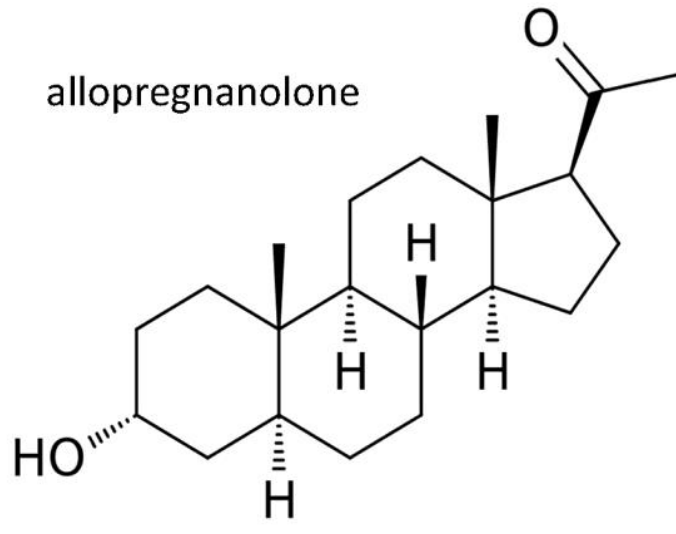

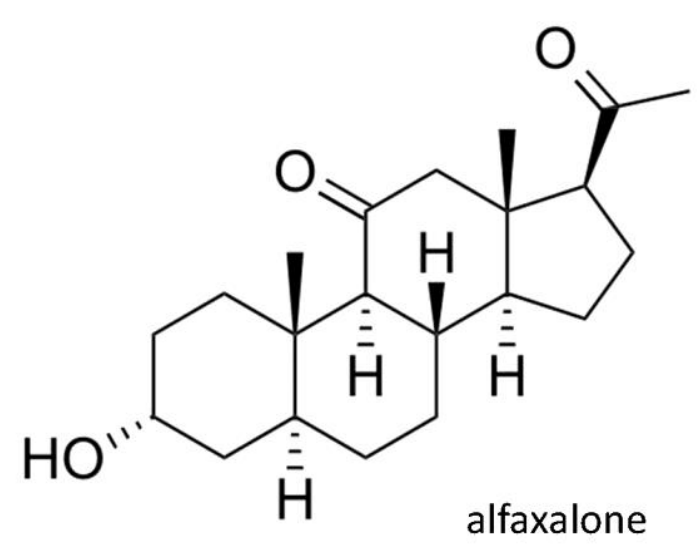




\section{Materials and methods}

\section{Assay Platform}

The activation of h-PXR by allopregnanolone and alfaxalone was measured using an in-vitro preparation by INDIGO Biosciences, Inc., 1981 Pine Hall Road, State College, PA, USA. This consisted of suspensions of "reporter cells" in multi well plates; human cells (HEK293) expressing the nuclear receptor, h-PXR (NR1I2). These cells were engineered to express a hybrid h-PXR, in which the $\mathrm{N}$-terminal sequence encoding the binding domain was substituted with yeast GAL4-binding domain. The rest of the native h-PXR, i.e., the ligand binding and C-terminal domains, remained intact and functional. Ligand (e.g., allopregnanolone) interaction with the receptor, caused it to bind to the GAL4 DNA binding sequence. The latter was functionally linked to firefly luciferase reporter gene. Binding with, and activation of the h-PXR, caused downstream changes in luciferase activity and light emission from the treated reporter cells. That luminescence was measured as relative light units (RLU) using a plate-reading luminometer, thus measuring the changes in h-PXR activity caused by the ligand applied to the HEK293 cells in each well plate.

\section{Test Compounds}

The test compounds alfaxalone and allopregnanolone were obtained from Sigma-Aldrich (400 Summit Drive, Burlington, MA 0180).

\section{Assay Methods}

A suspension of reporter cells was prepared in cell recovery medium. Stock solutions of allopregnanolone and alfaxalone were diluted in dimethyl sulfoxide (DMSO) to generate concentrated stock solutions (1000 x the highest test concentration). These intermediate 
stocks were diluted directly into compound screening medium containing $10 \%$ charcoalstripped foetal bovine serum to generate allopregnanolone and alfaxalone treatment solutions with concentrations at double the final planned testing levels: 100,000; 33,333; 11,111; 3,704, 1,235; and $412 \mathrm{nM}$ respectively. $100 \mu \mathrm{L}$ of each prepared treatment solution was dispensed into quadruplicate assay wells pre-filled with a $100 \mu \mathrm{L}$ suspension of reporter cells, thereby achieving the desired final treatment concentrations as shown in Table 1. The concentration of residual DMSO in all assay wells was $0.1 \%$.

Assay plates were incubated for $22-24 \mathrm{~h}$ in a cell culture incubator $\left(37^{\circ} \mathrm{C} / 5 \% \mathrm{CO} 2 / 85 \%\right.$ humidity). Following the incubation period, the treatment media were discarded and 100 $\mu \mathrm{L}$ of luciferase detection reagent (Indigo Biosciences) was added to each well. The resulting luminescence (relative light units; RLUs) was measured in each well using a luminometer. The recording from each well was entered into an Excel spreadsheet. Agonist concentration/activity response curves were plotted with non-linear curve fitting, using GraphPad Prism software (version 8.4.1; GraphPad Software, 2365 Northside Dr. Suite 560, San Diego, CA 92108). 


\section{Results}

Allopregnanolone and alfaxalone both produced aqueous solutions up to maximum concentration of $50,000 \mathrm{nM}$ in $0.1 \%$ DMSO. Higher concentrations of drug were not possible because the higher concentrations of DMSO necessary to achieve drug dissolution disrupt normal functions of the HEK reporter cells. Both pregnane steroids activated the hybrid h-PXR to cause dose-related light production by the linked firefly luciferase compared with control (DMSO) solutions (table 1 and figure 2).

\begin{tabular}{|c|c|c|c|c|c|}
\hline Compound & Concentration nM & \multicolumn{4}{|c|}{$\begin{array}{c}\text { Luminescence } \\
\text { (relative light units) }\end{array}$} \\
\hline \multirow{4}{*}{ alfaxalone } & 206 & 937 & 579 & 701 & 655 \\
\cline { 2 - 6 } & 617 & 869 & 733 & 873 & 617 \\
\cline { 2 - 6 } & 1,852 & 937 & 971 & 915 & 707 \\
\cline { 2 - 6 } & 5,556 & 1,431 & 1,461 & 1,475 & 1,293 \\
\cline { 2 - 6 } & 16,667 & 3,123 & 2,307 & 2,747 & 2,555 \\
\hline DMSO & 50,000 & 4,947 & 6,074 & 5,385 & 4,637 \\
\hline \multirow{3}{*}{ allopregnanolone } & $0.10 \%$ & \multicolumn{4}{|c|}{ average of 6 wells $=666$} \\
\cline { 2 - 6 } & 206 & 773 & 743 & 779 & 851 \\
\cline { 2 - 6 } & 617 & 739 & 763 & 789 & 725 \\
\cline { 2 - 6 } & 1,852 & 715 & 811 & 775 & 675 \\
\cline { 2 - 6 } & 5,556 & 1,103 & 905 & 951 & 885 \\
\cline { 2 - 6 } & 16,667 & 2,021 & 1,983 & 1,865 & 2,101 \\
\hline
\end{tabular}

Table 1.

hPXR Assay Results: The luminescence (expressed as relative light units, RLU) caused by a range of concentrations of allopregnanolone and alfaxalone; four wells at each concentration. Background luminescence of $0.1 \%$ solution of dimethyl sulfoxide (DMSO), the solution used to dissolve the neurosteroids, is also shown.

Demonstration of the maximum dose response for alfaxalone was not possible because of the inability to prepare more concentrated solutions with DMSO. Analysis of the $\log _{10}$ ligand 
concentration response relationships (Figure 2; GraphPad Prism 8 software) revealed that the allopregnanolone concentration that caused 50\% of maximum effect (EC50) was 9192, 6716 - $12581 \mathrm{nM}($ mean, 95\% CI); a comparable figure for alfaxalone could not be calculated because the maximal response was not achieved .

\section{Figure 2}

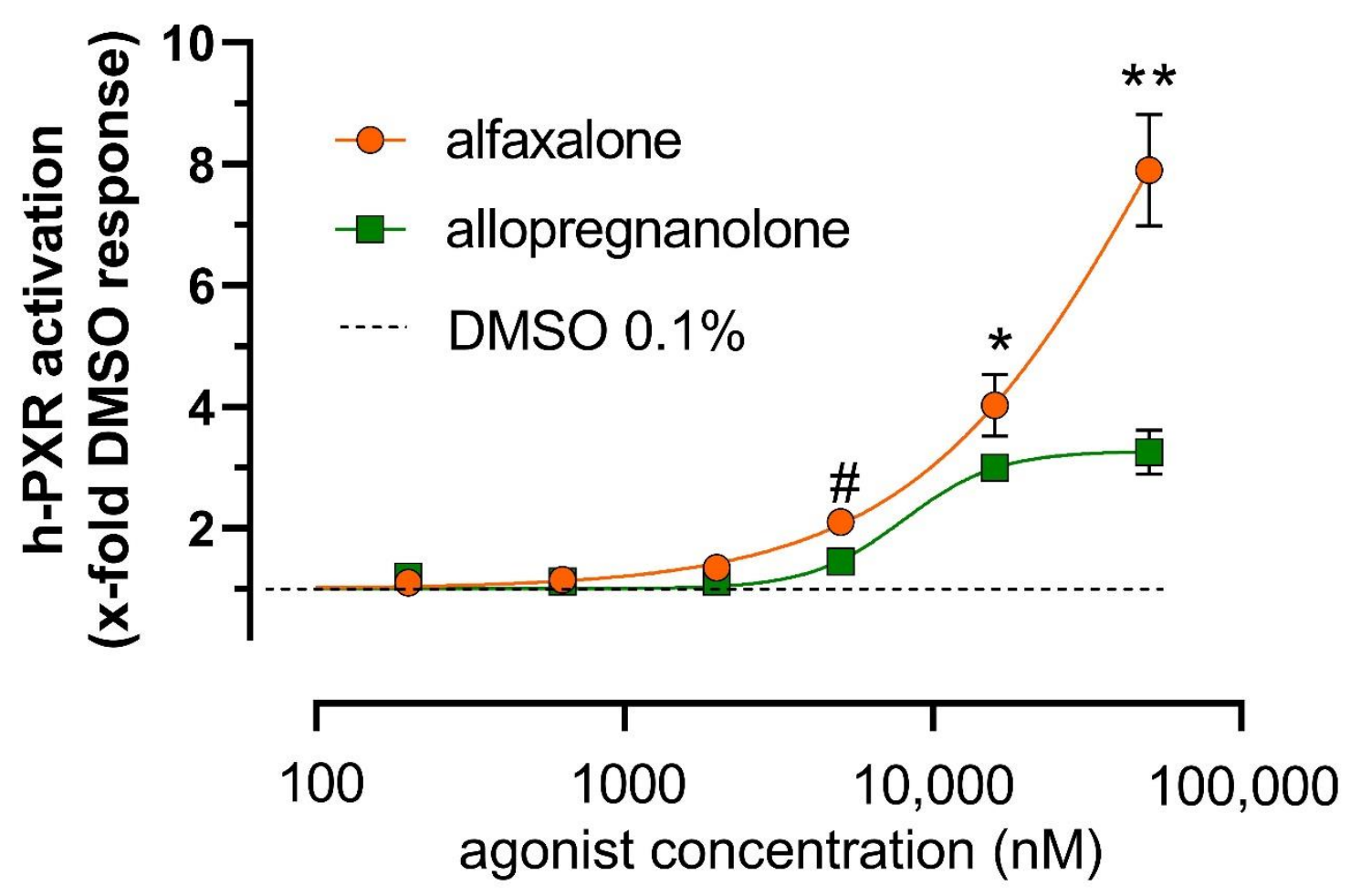

Ligand log concentration dose response curves: hPXR activation. Luminescence caused by the ligand interaction with h-PXR in each well was expressed as a multiple of the average luminescence caused by $0.1 \%$ DMSO vehicle controls $(n=6)$. Points shown are means $(n=4)$ and bars $\pm 95 \%$ confidence intervals (not shown if smaller than the symbol size). Statistical comparison using Brown-Forsythe and Welch ANOVA (GraphPad Prism version 8.4.1) confirmed alfaxalone is more efficacious than allopregnanolone in activating h-PXR at: $50,000 \mathrm{nM}[* *, \mathrm{p}=0.0019] ; 16,700 \mathrm{nM}[*, \mathrm{p}=0.0472] ;$ and 5,600 $\mathrm{nM}[\#, \mathrm{p}=0.0031]$. 
bioRxiv preprint doi: https://doi.org/10.1101/2020.09.05.284075; this version posted September 6,2020 . The copyright holder for this preprint (which was not certified by peer review) is the author/funder, who has granted bioRxiv a license to display the preprint in perpetuity. It is made available under aCC-BY-NC-ND 4.0 International license.

However, the maximum values at the top of the log concentration response curves, expressed as $\mathrm{x}$-fold activation of h-PXR (control DMSO =1) by 50,000 $\mathrm{nM}$ solutions were very different for the two ligands: 3.25, 2.66 - 3.83 (allopregnanolone mean, 95\% CI); 7.90, 6.44 - 9.36 (alfaxalone mean, 95\% CI) [p=0.0019; Brown-Forsythe and Welch ANOVA - figure 2]. Furthermore, h-PXR activation by lower intermediate concentrations of the two agonists were also significantly different: $16,700 \mathrm{nM}, \mathrm{p}=0.0472 ; 5,600 \mathrm{nM}, \mathrm{p}=0.0031$ [Figure 2; Brown-Forsythe and Welch ANOVA], alfaxalone being the more efficacious compound in activating h-PXR. 


\section{Discussion}

The results of the study reported here show that alfaxalone does bind with and activates hPXR and further that it is a more efficacious ligand than allopregnanolone in activating $\mathrm{h}-$ PXR in this model. Conclusions about the relative potency of the two pregnane ligands were not possible because the plateau portion of the alfaxalone $\log _{10}$ concentration response curve was not demonstrated. This was due to the inability to dissolve alfaxalone in water using $0.1 \%$ DMSO at concentrations higher than 50,000 $\mathrm{nM}$. This result suggests that sedation and anesthesia achieved using alfaxalone may be accompanied by the effects caused by interaction of allopregnanolone with brain PXR such as stimulating the production of BDNF ${ }^{5-8}$, which has been shown to have important roles in regulation of neurogenesis, gliogenesis, and synaptogenesis, as well as in neuroprotection, and control of short- and long- lasting synaptic interactions that determine memory and cognition $9 ; 17$.

See Figure 3 for a schematic representation of the relationships between neurosteroids, PXR and BDNF and their effects on brain and neuronal function under conditions of anesthesia, stress, trauma, and inflammation. PXR activation by alfaxalone may also inhibit microglial hyperinflammatory responses in the central nervous system via neuroimmune regulatory proteins, such as CD55 ${ }^{18 ; 19}$. Glial-mediated inflammation in the CNS is caused by many factors such as trauma, hypoxia, stress, and also by $\beta$-amyloid in Alzheimer's disease, all of which are common co-morbidities that complicate surgery and lead to poorer postoperative cognitive function ${ }^{19-21}$. Glial-mediated inflammation is also a cause of deficits in cognition after bacterial and viral infections, such as COVID-19 ${ }^{22}$. Alfaxalone sedation and anesthesia with simultaneous activation of PXR as described above clearly has the potential for improved CNS recovery. 


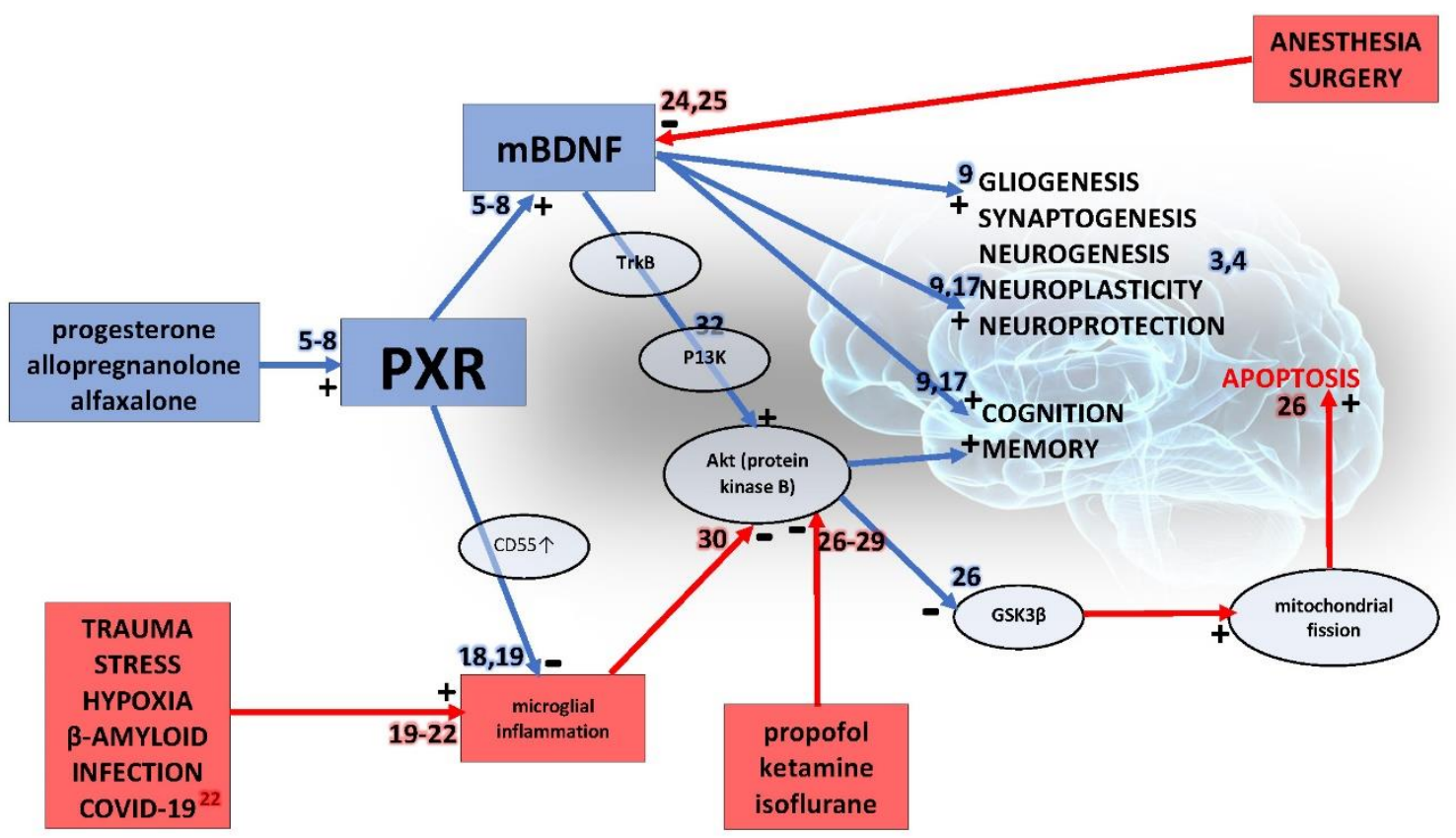

\section{Figure 3}

\section{A schematic representation of the relationships between neurosteroids, PXR and BDNF}

and their effects on brain and neuronal function under conditions of anesthesia, stress,

trauma, and inflammation. Neurosteroids progesterone, allopregnanolone and the

neuroactive steroid alfaxalone bind with and activate pregnane $\mathrm{X}$ receptors (PXR) to cause

increased production of mature brain derived neurotrophic factor (mBDNF) leading to

neuroprotection and preservation of cognition in the face of trauma, stress, infection and the

presence of anesthetics.

Arrows denote a causal relationship, red for deleterious and blue for beneficial effects on

brain function. A “+” or "_“ next to an arrow indicates a positive effect or negative effect on the target of the arrow.

Small numbers adjacent to arrows refer to papers in the reference list, red background denoting deleterious effects and blue denoting beneficial effects 
Alfaxalone is being developed for sedation and anesthesia in humans ${ }^{12 ; 13}$. This occurs at a time of controversy in anesthesia and critical care. Many preclinical studies published in the last two decades have reported neuronal damage and long-lasting cognitive impairment after administration of anesthetics, particularly to neonates and juveniles ${ }^{23}$. It is debated whether these effects translate into human anesthesia practice and the root causes of the effects are controversial; neurotoxicity of the anesthetic drugs per se or neuronal damage and dysfunction caused by surgery, stress, infection, hypoxia, etc. as discussed above. However, it is true to say that all current commonly used anesthetic drugs have been reported to be neurotoxic in young animals. The United States Food and Drug Administration has issued an advisory warning concerning the possible dangers of administering those drugs in late-stage pregnancy and to babies and young children [https://www.fda.gov/drugs/drug-safety-andavailability/fda-drug-safety-communication-fda-review-results-new-warnings-about-usinggeneral-anesthetics-and]. At the other end of the age spectrum, anesthetic drugs and surgery have been linked with acute delirium and long-term deficits in cognition in older persons ${ }^{24}$. These have been linked to low levels of $\mathrm{BDNF}^{25}$.

There are reports citing precise mechanisms for neurotoxicity of anesthetic drugs per se. Liu et al showed that propofol causes dose-dependent neuronal cell death at clinically relevant concentrations through a mitochondrial pathway; Akt (protein kinase B)/glycogen synthase kinase-3 (GSK3) ${ }^{26}$. See Figure 3. This mechanism for neurotoxicity is also activated by ketamine and inhalational agents such as isoflurane ${ }^{27-29}$. Further, the apoptosis caused by persistent neuroinflammation has been shown to involve the same Akt pathway as shown in Figure $3^{30}$. Sevoflurane anesthesia has been shown to induce an increase in the levels of proinflammatory cytokines in microglia, while decreasing activation of the phosphatidylinositol 3-kinase/protein kinase B (PI3K/Akt) pathway in both the cortex and hippocampus of rats. In 
bioRxiv preprint doi: https://doi.org/10.1101/2020.09.05.284075; this version posted September 6, 2020. The copyright holder for this preprint (which was not certified by peer review) is the author/funder, who has granted bioRxiv a license to display the preprint in perpetuity. It is made available under aCC-BY-NC-ND 4.0 International license.

that study, treatment with the anesthetic dexmedetomidine reduced pro-inflammatory cytokine levels and prevented inactivation of the PI3K/Akt pathway ${ }^{31}$. Liu et al observed that BDNF secretion by astrocytes inhibits the pro-apoptotic anesthetic-induced depression of $\mathrm{Akt}^{26}$. Mature BDNF (m-BDNF) binds at the cell surface with TrkB receptors to form a complex which activates a variety of intracellular signalling pathways, including PI3K ${ }^{32}$. This is shown in Figure 3. PI3K activation phosphorylates and activates Akt in the plasma membrane. The overall effect of m-BDNF increasing activity in these pathways is inhibition of apoptosis, stimulation of new cell growth (neurones and glia) and promotion of new dendrite and axonal growth and interconnections (neuroplasticity). Liu et al suggested that anesthetic-induced neurotoxicity occurs at times of relative paucity of astrocytes and the neuroprotective factor they produce; $\mathrm{BDNF}^{26}$. This paucity occurs in young and aged brains, so suggesting that adverse neurocognitive sequalae are more likely to occur when one or a combination of factors [toxins (anesthetics), inflammation (sepsis, stress, Alzheimer's proteins, extracorporeal circulation)] come together at these vulnerable times of life when the brain natural protective mechanisms are at their weakest. The implication of this notion is clear. Using alfaxalone for the anesthetic during those times, by activating PXR will tend to bolster the natural neuroprotective mechanisms.

Two examples published in the literature support this idea. First, Yawno et al showed in fetal lambs exhibiting increased neuronal apoptosis caused by inhibition of allopregnanolone synthesis that an anesthetic dose of alfaxalone prevented the apoptosis ${ }^{33}$. The second example concerns reperfusion injury in the CNS after stroke in which microglial inflammation is well established as a mechanism ${ }^{34}$. Preclinical studies have shown that progesterone and allopregnanolone suppress that inflammatory response and the apoptotic enzyme caspase-3, and also decrease cerebral infarct volume after experimental brain 
injury $^{35}$. Cervantes et al showed that a single anesthetic dose of alfaxalone administered immediately after restoration of normal brain perfusion prevented severe neurological damage caused by 8 minutes cardiorespiratory arrest in cats ${ }^{36}$.

More recently it has been reported that alfaxalone is not neurotoxic to the developing brain ${ }^{14}$. This report is reassuring but the results of the study reported herein suggest that alfaxalone anesthesia may also be accompanied by positive effects on neuronal function mediated by PXR activation, protecting neurons from the adverse effects of surgical stress and other comorbidities commonly found in patients presenting for surgery ${ }^{37-39}$.

\section{Study Limitations}

The limitation of this study lies in question of relevance of the in vitro system to the in vivo situation. The in vitro cell culture approach provides benefits of investigating h-PXR activation under controlled conditions without interference of confounding physiological or pathological factors seen in the intact animal model. However, the in vitro system is artificial and interactions between different cell types in intact animals is missing. It is therefore important to confirm in vitro findings using an intact animal model. To that end, it is important to note data already published by Yawno and colleagues that showed normal anesthetic doses of alfaxalone can replace allopregnanolone in the control of apoptosis in fetal lambs, an effect of allopregnanolone-PXR referred to above ${ }^{33}$. Although the study reported herein used in vitro methods, the naturally occurring and active hormone, allopregnanolone, was used as an active control. The results show that allopregnanolone was active in this model and further that alfaxalone was more efficacious than allopregnanolone in h-PXR activation. 


\section{Reference List}

1. Frye CA, Koonce CJ, Walf AA: Novel receptor targets for production and action of allopregnanolone in the central nervous system: a focus on pregnane xenobiotic receptor. Front Cell Neurosci. 2014; 8: 106

2. Torres-Vergara P, Ho YS, Espinoza F, Nualart F, Escudero C, Penny J: The constitutive androstane receptor and pregnane X receptor in the brain. Br.J.Pharmacol. 2020;

3. Singh C, Liu L, Wang JM, Irwin RW, Yao J, Chen S, Henry S, Thompson RF, Brinton RD: Allopregnanolone restores hippocampal-dependent learning and memory and neural progenitor survival in aging 3xTgAD and nonTg mice. Neurobiol.Aging 2012; 33: 1493-506

4. Brinton RD: Neurosteroids as regenerative agents in the brain: therapeutic implications. Nat.Rev.Endocrinol. 2013; 9: 241-50

5. Langmade SJ, Gale SE, Frolov A, Mohri I, Suzuki K, Mellon SH, Walkley SU, Covey DF, Schaffer JE, Ory DS: Pregnane X receptor (PXR) activation: a mechanism for neuroprotection in a mouse model of Niemann-Pick C disease. Proc.Natl.Acad.Sci.U.S.A 2006; 103: 13807-12

6. Cooke PS, Nanjappa MK, Yang Z, Wang KK: Therapeutic effects of progesterone and its metabolites in traumatic brain injury may involve non-classical signaling mechanisms. Front Neurosci. 2013; 7: 108

7. Lamba V, Yasuda K, Lamba JK, Assem M, Davila J, Strom S, Schuetz EG: PXR (NR1I2): splice variants in human tissues, including brain, and identification of neurosteroids and nicotine as PXR activators. Toxicol.Appl.Pharmacol. 2004; 199: 251-65

8. Frye CA, Koonce CJ, Walf AA: Involvement of pregnane xenobiotic receptor in mating-induced allopregnanolone formation in the midbrain and hippocampus and brain- 
derived neurotrophic factor in the hippocampus among female rats. Psychopharmacology $2014 ; 231: 3375-90$

9. Kowianski P, Lietzau G, Czuba E, Waskow M, Steliga A, Morys J: BDNF: A Key Factor with Multipotent Impact on Brain Signaling and Synaptic Plasticity. Cell Mol.Neurobiol. 2018; 38: 579-93

10. Cottrell GA, Lambert JJ, Peters JA: Modulation of GABAA receptor activity by alphaxalone. Br.J.Pharmacol. 1987; 90: 491-500

11. Child KJ, English AF, Gilbert HG, Woollett EA: An endocrinological evaluation of Althesin (CT 1341) with special reference to reproduction. Postgrad.Med.J. 1972; 48: Suppl5

12. Goodchild CS, Serrao JM, Kolosov A, Boyd BJ: Alphaxalone Reformulated: A WaterSoluble Intravenous Anesthetic Preparation in Sulfobutyl-Ether-beta-Cyclodextrin. Anesth.Analg. 2015; 120: 1025-31

13. Monagle J, Siu L, Worrell J, Goodchild CS, Serrao JM: A Phase 1c Trial Comparing the Efficacy and Safety of a New Aqueous Formulation of Alphaxalone with Propofol. Anesth.Analg. 2015; 121: 914-24

14. Tesic V, Joksimovic SM, Quillinan N, Krishnan K, Covey DF, Todorovic SM, Jevtovic-Todorovic V: Neuroactive steroids alphaxalone and CDNC24 are effective hypnotics and potentiators of $\mathrm{GABA}_{\mathrm{A}}$ currents, but are not neurotoxic to the developing rat brain. Br.J.Anaesth. 2020; 124: 603-13

15. Jevtovic-Todorovic V: Anaesthesia-induced developmental neurotoxicity: reality or fiction? Br.J.Anaesth. 2017; 119: 455-7

16. Jevtovic-Todorovic V: Functional implications of an early exposure to general anesthesia: are we changing the behavior of our children? Mol.Neurobiol. 2013; 48: 288-93 
17. Huang EJ, Reichardt LF: Neurotrophins: roles in neuronal development and function. Annu.Rev.Neurosci. 2001; 24: 677-736

18. Griffiths M, Neal JW, Gasque P: Innate immunity and protective neuroinflammation: new emphasis on the role of neuroimmune regulatory proteins. Int.Rev.Neurobiol. 2007; 82: $29-55$

19. VanLandingham JW, Cekic M, Cutler S, Hoffman SW, Stein DG: Neurosteroids reduce inflammation after TBI through CD55 induction. Neurosci.Lett. 2007; 425: 94-8

20. Lue LF, Beach TG, Walker DG: Alzheimer's Disease Research Using Human Microglia. Cells 2019; 8:

21. Kaur D, Sharma V, Deshmukh R: Activation of microglia and astrocytes: a roadway to neuroinflammation and Alzheimer's disease. Inflammopharmacology. 2019; 27: 663-77

22. Wu Y, Xu X, Chen Z, Duan J, Hashimoto K, Yang L, Liu C, Yang C: Nervous system involvement after infection with COVID-19 and other coronaviruses. Brain Behav.Immun. 2020; 87: 18-22

23. Jevtovic-Todorovic V: Exposure of Developing Brain to General Anesthesia: What Is the Animal Evidence? Anesthesiology 2018; 128: 832-9

24. Chen PL, Yang CW, Tseng YK, Sun WZ, Wang JL, Wang SJ, Oyang YJ, Fuh JL: Risk of dementia after anaesthesia and surgery. Br.J.Psychiatry 2014; 204: 188-93

25. Wyrobek J, LaFlam A, Max L, Tian J, Neufeld KJ, Kebaish KM, Walston JD, Hogue CW, Riley LH, Everett AD, Brown CH: Association of intraoperative changes in brainderived neurotrophic factor and postoperative delirium in older adults. Br.J.Anaesth. 2017; 119: $324-32$

26. Liu Y, Yan Y, Inagaki Y, Logan S, Bosnjak ZJ, Bai X: Insufficient Astrocyte-Derived Brain-Derived Neurotrophic Factor Contributes to Propofol-Induced Neuron Death Through 
Akt/Glycogen Synthase Kinase 3beta/Mitochondrial Fission Pathway. Anesth.Analg. 2017; 125: $241-54$

27. Liu JR, Baek C, Han XH, Shoureshi P, Soriano SG: Role of glycogen synthase kinase3beta in ketamine-induced developmental neuroapoptosis in rats. Br.J.Anaesth. 2013; 110 Suppl 1: i3-i9

28. Tao G, Xue Q, Luo Y, Li G, Xia Y, Yu B: Isoflurane Is More Deleterious to Developing Brain Than Desflurane: The Role of the Akt/GSK3beta Signaling Pathway. Biomed.Res.Int. 2016; 2016: 7919640

29. Li Y, Zeng M, Chen W, Liu C, Wang F, Han X, Zuo Z, Peng S: Dexmedetomidine reduces isoflurane-induced neuroapoptosis partly by preserving PI3K/Akt pathway in the hippocampus of neonatal rats. PLoS.One. 2014; 9: e93639

30. Cianciulli A, Porro C, Calvello R, Trotta T, Lofrumento DD, Panaro MA: Microglia Mediated Neuroinflammation: Focus on PI3K Modulation. Biomolecules. 2020; 10:

31. Wang N, Wang M: Dexmedetomidine suppresses sevoflurane anesthesia-induced neuroinflammation through activation of the PI3K/Akt/mTOR pathway. BMC.Anesthesiol. 2019; 19: 134

32. King D, Yeomanson D, Bryant HE: PI3King the lock: targeting the PI3K/Akt/mTOR pathway as a novel therapeutic strategy in neuroblastoma. J.Pediatr.Hematol.Oncol. 2015; 37: $245-51$

33. Yawno T, Hirst JJ, Castillo-Melendez M, Walker DW: Role of neurosteroids in regulating cell death and proliferation in the late gestation fetal brain. Neuroscience 2009; 163: $838-47$

34. Danton GH, Dietrich WD: Inflammatory mechanisms after ischemia and stroke. J.Neuropathol.Exp.Neurol. 2003; 62: 127-36 
35. He J, Evans CO, Hoffman SW, Oyesiku NM, Stein DG: Progesterone and allopregnanolone reduce inflammatory cytokines after traumatic brain injury. Exp.Neurol. 2004; 189: 404-12

36. Cervantes M, Ruelas R, Sanchez R, Alvarez-Resendiz G: Brain injury following cardiorespiratory arrest in cats. Effects of alphaxalone-alphadolone. Bol.Estud.Med.Biol. $1989 ; 37: 17-27$

37. Tian XS, Tong YW, Li ZQ, Li LX, Zhang T, Ren TY, Zhou T, Wang HC, Zhan R, Sun Y, Yan Z, Wang QD, Fan DS, Kong FJ, Guo XY, Xiao WZ, Chui DH: Surgical stress induces brain-derived neurotrophic factor reduction and postoperative cognitive dysfunction via glucocorticoid receptor phosphorylation in aged mice. CNS.Neurosci.Ther. 2015; 21 : $398-409$

38. Della GA, Goldim MP, Danielski LG, Florentino D, Garbossa L, Joaquim L, Oliveira Junior AN, Mathias K, Fileti ME, Zarbato GF, da RN, Laurentino AOM, Fortunato JJ, Palandi J, de Oliveira BH, Martins DF, Bonbinski F, Bellettini-Santos T, Garcez M, Budni J, Barichello T, Petronilho F: Fish oil-rich lipid emulsion modulates neuroinflammation and prevents long-term cognitive dysfunction after sepsis. Nutrition 2020; 70: 110417

39. Vaidya VA, Terwilliger RM, Duman RS: Role of 5-HT2A receptors in the stressinduced down-regulation of brain-derived neurotrophic factor expression in rat hippocampus. Neurosci.Lett. 1999; 262: 1-4 